\title{
Evaluation of Heat and Cold wave events over West Africa
}

\author{
Ifeka Adolphus $^{1^{*}}$, Balogun Ifeoluwa A. ${ }^{1}$, Akinbobola Ademola ${ }^{1}$ and Balogun Richard A. ${ }^{1}$ \\ ${ }^{1}$ Department of Meteorology and Climate Science, Federal University of Technology Akure, Nigeria \\ *Corresponding Author: adolphusifeka@yahoo.com \\ DOI: $10.31364 /$ SCIRJ/v9.i09.2021.P0921879 \\ http://dx.doi.org/10.31364/SCIRJ/v9.i09.2021.P0921879
}

\begin{abstract}
This study evaluated Heat and Cold wave events in the homogenous temperature regions over West Africa. ERA5 reanalysis daily minimum and maximum data from 1979-2018 were used as the surrogate observed data and Heat/cold wave events were calculated using 1979-2008 as a reference period. Results show that the retained four PCs explain 78.27\% percentage of variance in the daily maximum temperature data for March, April and May. For the 1979-2008 period, $53.99 \%$ of variance is explained by the PC1, $14.52 \%$ of variance is explained by PC2, PC3 revealed $6.34 \%$ of variance and $3.42 \%$ of variance is explained by PC4. The retained four PCs explain $49.88 \%$ percentage of variance in the daily maximum temperature data for June, July, August and September. $27.29 \%$ of variance is explained by PC1, $10.31 \%$ of variance is explained by $\mathrm{PC} 2, \mathrm{PC} 3$ revealed $6.28 \%$ and $5.80 \%$ of variance is explained by PC4 for the month of June, July, August and September. There are highly negative component loadings $(<-0.5)$ which are located at along the southern Guinea savanna and the fringes of the coastal cities over West Africa for March, April and May (MAM) and June, July, August and September (JJAS). Generally, PC1 and PC2 depicted to be the major contributors in the temperature variations over the land, places with high PC loadings are expected to be hotter on days with high positive PC score and colder on days with highly negative PC score.

Heat wave amplitude has significantly increased $90^{\text {th }}$ percentile from $1979-2008$ with the highest value of $2.9^{\circ} \mathrm{C}$ in 2002 and a corresponding 17 days of heatwave duration in 1998 over Sudan-Sahel while the Guinea coast indicated an increase in the heat wave amplitude with the peak value $32.56^{\circ} \mathrm{C}$ in 1987 at $90^{\text {th }}$ percentile, the heatwave duration increased from $1979-2008$ with a record of 14 days in 1987. Cold waves were evident with a peak in amplitude of $-43.4^{\circ} \mathrm{C}$ at $90^{\text {th }}$ percentile in 2002 over Guinea coast and duration of the cold waves recorded highest event of 14 days in 1987 at $90^{\text {th }}$ percentile. The findings revealed a warming trend in the present and possible future climate of West Africa and the temperature increase could pose a serious threat on socioeconomic activities, which necessitates a call to action for possible climate adaption and mitigation pathways for policymakers and planning.
\end{abstract}

Keywords: Heatwaves, Cold waves, homogenous temperature regions, Guinea coast.

\section{Introduction}

Heat wave is an extended period of excessively hot and sometimes also humid weather relative to normal climate patterns for the seasons in a certain region. Heat wave causes temporary modifications in lifestyle and may have adverse health effects on the affected population depending on the intensity (Robinson, 2001). Perkins et al. (2012) defined heat waves as a period of consecutive days where conditions are excessively hotter than normal. Most of the widely used extreme temperature indices take into account only one aspect (i.e., maximum temperature, duration, or frequency) during a defined period, which is not necessarily part of a heat spell, and it is from the global perspective (Perkins et al.,2013)

To date, the definition of heatwave is hardly conclusive around the world as population acclimatization and adaptation may differ from climates and regions (Tong et al., 2015; Xu et al., 2016; Yang et al., 2018). Several studies have calculated heat and cold stresses using different indices. Watts and Kalkstein (2004) developed the Heat stress index while (Frich et al.2002; Peterson, 2002; Donat et al., 2013) used indices developed by the Expert Team on Climate Change Detection and Indices (ETCCDI). (Alexander et al.,2006 and Meehl and Tebaldi; 2004) defined and calculated heat or cold waves with a number of time steps in daily maximum or minimum temperature above a particular threshold value. Easterling et al., (1997) defined heat wave event as at least three days with a maximum temperature above the $80^{\text {th }}$ percentile (based on reference period) for that day followed by a minimum temperature above the $80^{\text {th }}$ percentile for that day. Nairn and Fawcett (2013) defined heat waves by using mean temperature which is the average of the minimum and maximum daily temperature. They computed excess heat index as an abnormal heat originating from a high afternoon temperature that is not cooled during the night hours as a result of relatively high night time temperature. They used $95^{\text {th }}$ and $5^{\text {th }}$ percentile threshold for the computation.

www.sciri.org

(C) 2021, Scientific Research Journal

http://dx.doi.org/10.31364/SCIRJ/v9.i09.2021.P0921879

This publication is licensed under Creative Commons Attribution CC BY. 
Although heat wave definitions vary across world, as this definition depends on climatic zone, duration of heat wave, and metric of temperature and humidity and even winds in a lesser extent, some invariable metrics remain. To quantitatively reflect a heat wave event, the definition of heat wave should be complemented by the characterization of the following four metrics: (1) Magnitude: it should be computed based on an index or a set of indices of thermal condition(s) exceeding certain threshold(s), (2) Duration: which involves the computation of the persistence of a heat wave and should be based on recording the start time and the end time of the event, (3) Severity: it is a measurement method which integrates two aspects of the event, its magnitude and its persistence, and (4) Extent: it is computed to inform on the geographical area affected and the widespread the heat wave. Few researchers use hot days and nights (Yil et., al 2017, Habeeb D et. al., 2005) as metrics of temperature, to define heat wave; they propose relative threshold or absolute threshold (fixed threshold) (Guo Y et al.,2017, Smith et. al., 2013). Another study, conducted in West Africa, has used temperature 90th percentile of both minimum and maximum temperature (Moron et. al., 2016).

This paper aims at evaluating the variations of heat and cold waves in homogeneous temperature region over West Africa. Surrogate observed (ERA-5 reanalysis) data were used to delineate West Africa into homogeneous daily temperature regions for the heat and cold waves to be documented for planning and policy making in possible adaptation and mitigation. It further computed the heat and cold waves events over Sudan-Sahel and Guinea Coast Zones.

\section{Data and methodology}

\section{Study locality}

The domain of the study lies within Latitude $0^{\circ} \mathrm{N}-20^{\circ} \mathrm{N}$ and Longitude $20^{\circ} \mathrm{W}-20^{\circ} \mathrm{E}$, two agroclimatic zones were selected based on weather and climate pattern similarities together with the ecosystem (Omotosho and Abiodun, 2007). These zones are Guinea Coast and Sudan-Sahel. It is bounded in the south by Atlantic Ocean, north by Sahara Desert and Cameroon highland in the east.

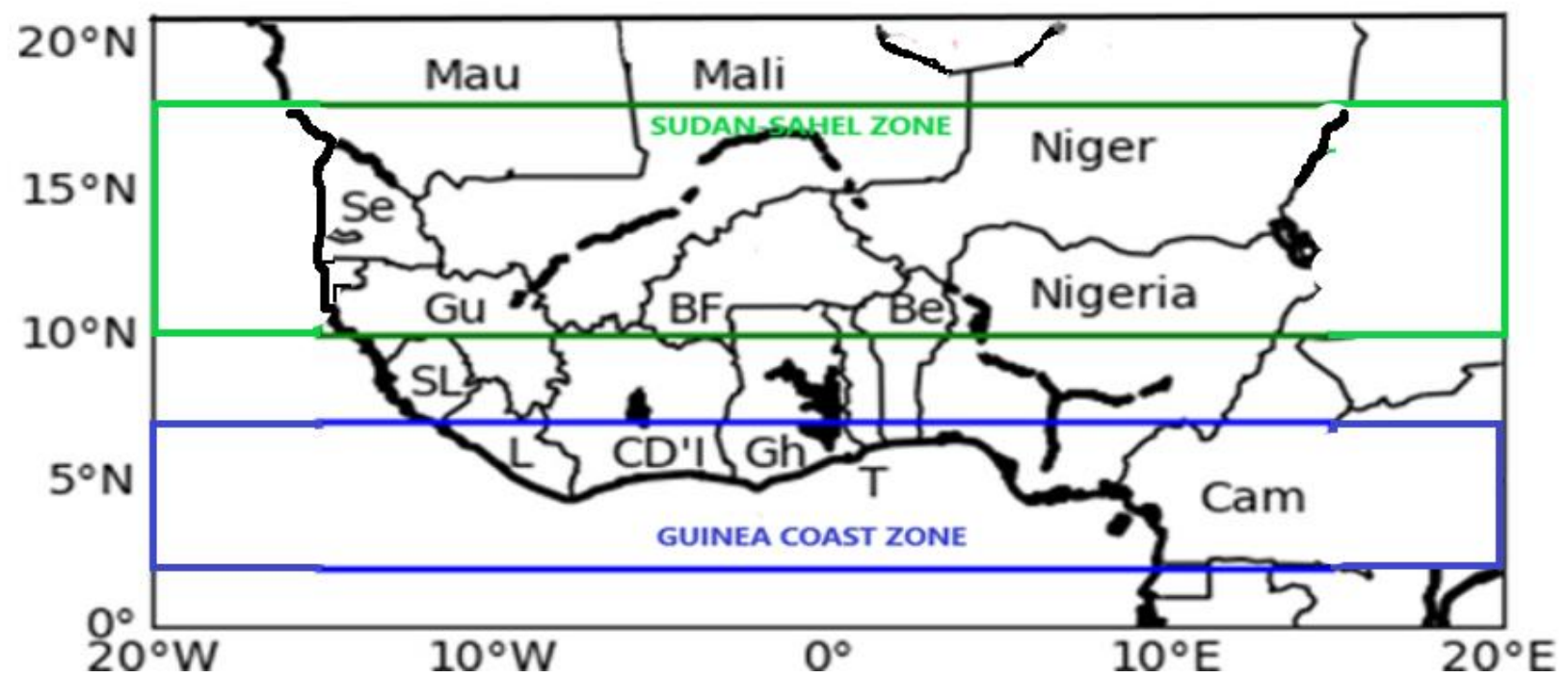

Figure 1: Study area map of West Africa showing the zones (Sudan-Sahel and Guinea Coast) blue box denotes the Guinea Coast zone $\left(20^{\circ} \mathrm{W}-20^{\circ} \mathrm{E}, 2-7^{\circ} \mathrm{N}\right)$, whilst the green box highlights the Sudan-Sahel $\left(20^{\circ} \mathrm{W}-20^{\circ} \mathrm{E}, 10-18^{\circ} \mathrm{N}\right)$ zone discussed in the study. Country abbreviations (black text) from north to south are as follows: Mau, Mauritania; TG, The Gambia; Se, Senegal; GB, Guinea-Bissau; Gu, Guinea; BF, Burkina Faso; Be, Benin; SL, Sierra Leone; L, Liberia; CD’I, Cote D’Ivoire (Ivory Coast); Gh, Ghana; T, Togo; Cam, Cameroon. 


\section{Methodology}

European Centre for Medium-Range Weather Forecast (ECMWF-ERA-5) reanalysis daily minimum and maximum temperature data from 1979-2018 were used as the surrogate observed data with spatial resolution of $0.25^{\circ} \times 0.25^{\circ}$. S-mode principal component analysis (PCA) based on hierarchical methods were used to delineate the daily temperature (ERA5) data into homogeneous daily temperature regions with similar variations.

$$
N_{c}=1+\left(3.3 \log _{10} n\right)
$$

where; $\quad N_{c}=$ maximum number of clusters and $\mathrm{n}$ is the number of items (stations) to be clustered.

Barlett's test of sphericity were used to determine whether there are relationships or common variance (Homogeneity) among the variables in the dataset.

$$
\mathrm{X}^{2}=\frac{(N-k) \operatorname{In}\left(s_{P}^{2}\right)-\sum_{i=0}^{k}\left(n_{i}-1\right) \operatorname{In}\left(s_{i}^{2}\right)}{1+\frac{1}{3(k-1)}\left(\sum_{i=1}^{k}\left(\frac{1}{n_{i-1}}\right)-\frac{1}{N-k}\right)}
$$

where; $\boldsymbol{s}_{\boldsymbol{i}}^{2}$ is the variance of the $i$ th group, $N$ is the total sample size, $N_{i}$ is the sample size of the $i$ th group, $k$ is the number of groups, and $s_{i}^{2}$ is the pooled variance.

The ClimPACT2 indices were derived from daily maximum and minimum temperatures using the definitions of Climate Indices from the Expert Team on Climate Change Detection and Indices (ETCCDI) representing more extreme aspects of climate (Perkins and Alexander, 2013)

Daily mean temperature $(\mathrm{TM})=(\mathrm{TX}+\mathrm{TN} / 2)$

where; $T X$ is the maximum temperature and $T N$ is the minimum temperature, respectively over 24 hours.

Diurnal temperature range $(\mathrm{DTR})=\mathrm{TX}-\mathrm{TN}$

Table 1: Core and Non-Core ET-SCI Indices calculated by ClimPACT2 (Perkins et al, 2013 and Nairn et al 2013)

\begin{tabular}{|l|l|l|l|l|}
\hline SHORT NAME & LONG NAME & DEFINITION & UNITS & TIME SCALE \\
\hline $\mathrm{TX}_{\mathrm{x}}$ & Max TX & Warmest daily TX or Hottest day & ${ }^{\circ} \mathrm{C}$ & Monthly/Annual \\
\hline $\mathrm{TX}_{\mathrm{n}}$ & Min TN & Coldest daily TN or Coldest night & ${ }^{\circ} \mathrm{C}$ & Monthly/Annual \\
\hline TX90th & $\begin{array}{l}\text { Very warm day } \\
\text { threshold }\end{array}$ & Value of $90^{\text {th }}$ Percentile of TX & ${ }^{\circ} \mathrm{C}$ & Daily \\
\hline TN90th & $\begin{array}{l}\text { Very cold day } \\
\text { threshold }\end{array}$ & Value of $90^{\text {th }}$ Percentile of TN & ${ }^{\circ} \mathrm{C}$ & Daily \\
\hline & & & \\
\hline
\end{tabular}




\begin{tabular}{|c|c|c|c|c|}
\hline EHF & Excess Heat Factor & $\begin{array}{l}\text { EHF is measure of the temperature } \\
\text { of a particular day relative to the } \\
\text { baseline period, with a measure of } \\
\text { the potential acclimatization that } \\
\text { occurred in the preceding } 30 \text { days. }\end{array}$ & ${ }^{\circ} \mathrm{C}$ & Daily \\
\hline HWA(EHF/Tx90/Tn90) & $\begin{array}{l}\text { Heatwave } \\
\text { amplitude (HWA) } \\
\text { defined by either } \\
\text { the excess the } \\
\text { Excess Heat Factor } \\
\text { (EHF), 90th } \\
\text { percentile of TX or } \\
\text { the } 90 \text { th percentile } \\
\text { of TN. }\end{array}$ & $\begin{array}{l}\text { The Peak daily value in the hottest } \\
\text { heatwaves or the hottest day of the } \\
\text { hottest heatwave. }\end{array}$ & $\begin{array}{l}{ }^{\circ} \mathrm{C}\left({ }^{\circ} \mathrm{C}^{2} \text { for }\right. \\
\text { EHF })\end{array}$ & Annual \\
\hline $\begin{array}{l}\text { HWD } \\
\text { (EHF/Tx90/Tn90) }\end{array}$ & $\begin{array}{l}\text { Heatwave duration } \\
\text { (HWD) as defined } \\
\text { by either the Excess } \\
\text { Heat Factor (EHF), } \\
\text { 90th percentile of } \\
\text { TX or the 90th } \\
\text { percentile of TN. }\end{array}$ & $\begin{array}{l}\text { The length of the longest heatwave } \\
\text { identified by Heatwave Number } \\
\text { (HWN) }\end{array}$ & days & Annual \\
\hline $\begin{array}{l}\text { HWM } \\
\text { (EHF/Tx90/Tn90) }\end{array}$ & $\begin{array}{l}\text { Heatwave } \\
\text { Magnitude (HWM) } \\
\text { as defined by either } \\
\text { the Excess Heat } \\
\text { Factor (EHF), 90th } \\
\text { percentile of TX or } \\
\text { the } 90 \text { percentile } \\
\text { of TN. }\end{array}$ & $\begin{array}{l}\text { The mean temperature of all } \\
\text { heatwaves identified by Heatwave } \\
\text { Number (HWN) }\end{array}$ & $\begin{array}{l}{ }^{\circ} \mathrm{C}\left({ }^{\circ} \mathrm{C}^{2} \text { for }\right. \\
\mathrm{EHF})\end{array}$ & Annual \\
\hline HWF(EHF/Tx90/Tn90) & $\begin{array}{l}\text { Heatwave } \\
\text { frequency (HWF) } \\
\text { as defined by either } \\
\text { the Excess Heat } \\
\text { Factor (EHF), 90th } \\
\text { percentile of TX or } \\
\text { the } 90 \text { th percentile } \\
\text { of TN. }\end{array}$ & $\begin{array}{l}\text { The number of days that contribute } \\
\text { to heatwaves as identified by } \\
\text { Heatwave Number (HWN) }\end{array}$ & days & Annual \\
\hline $\begin{array}{l}\text { HWN } \\
\text { (EHF/Tx90/Tn90) }\end{array}$ & $\begin{array}{l}\text { Heatwave number } \\
\text { (HWN) as defined } \\
\text { by either the Excess } \\
\text { Heat Factor (EHF), } \\
\text { 90th percentile of } \\
\text { TX or the 90th } \\
\text { percentile of TN. }\end{array}$ & $\begin{array}{l}\text { The number of individual } \\
\text { heatwaves that occur each summer } \\
\text { (Nov-March in southern } \\
\text { hemisphere and May-September in } \\
\text { northern hemisphere). } \\
\text { A heatwave is defined as } 3 \text { or more } \\
\text { days where either the EHF is } \\
\text { positive, TX>90th percentile of }\end{array}$ & events & Annual \\
\hline
\end{tabular}


TX or where $\mathrm{TN}>90$ th percentile of TN

\section{Results and discussion}

\section{PCA and Clusters}

Bartletts test of statistic (BTS) revealed the suitability of a Principal Component Analysis (PCA) analysis in the daily maximum temperature data over West Africa. The significance of the Bartletts test of statistic (BTS test) is also high ( $p>0.05$ ), this shows that there are common variances among the grids for the PCA to identify (Figure $2 \& 3$ ).
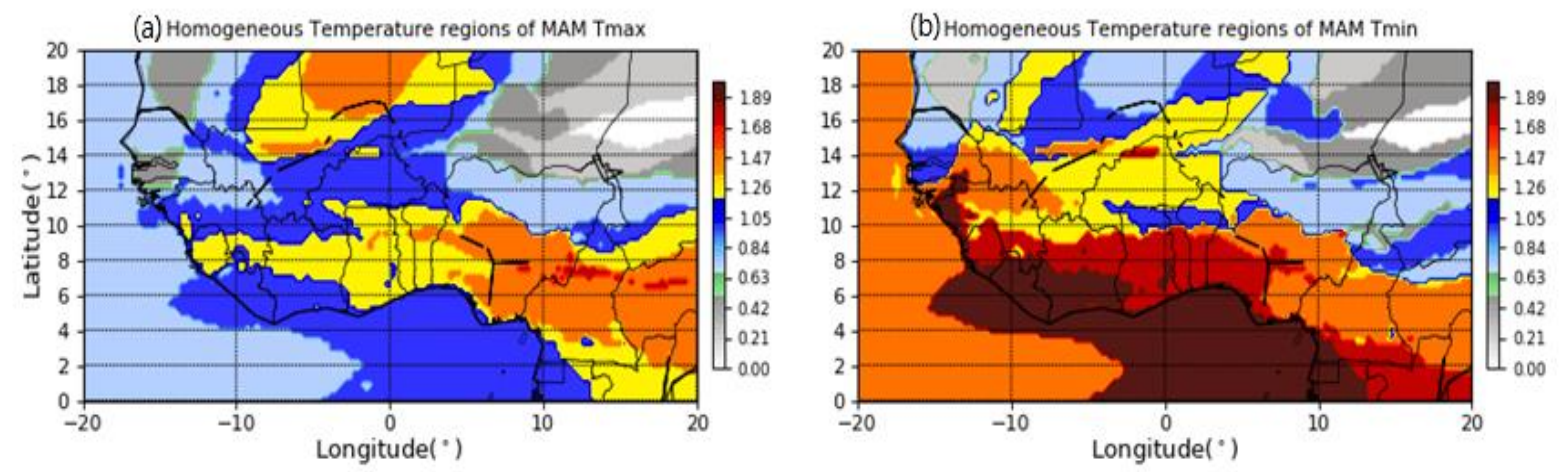

Figure 2: Cluster Analysis of Maximum and Minimum temperature showing the homogeneous temperature regions over West Africa during March, April and May (1979-2008)
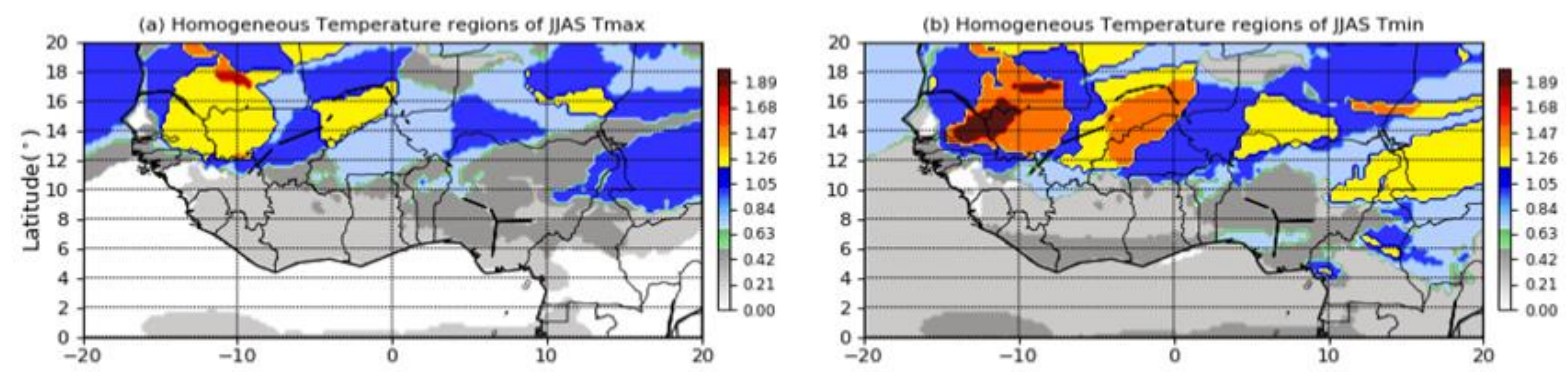

Figure 3: Cluster Analysis of Maximum and Minimum temperature showing the homogeneous temperature regions over West Africa during June, July, August and September (1979-2008)

The PCA conducted on the 10,950 days starting from 1st of January 1979 to 31st December 2008 produced four (4) significant PCs based on the Cartell (1966) Scree criteria and eigenvalue one rule, Kaiser (1960). The retained four PCs explain 78.27\% percentage of variance in the daily maximum temperature data for March, April and May. The percentage of explained variance in the maximum temperature data from the four PCs conducted differs for the 30-year period. For the 1979-2008 period, 53.99\% of variance is explained by the PC1, $14.52 \%$ of variance is explained by PC2, PC3 revealed $6.34 \%$ of variance and $3.42 \%$ of variance is explained by PC4 (Figure 4). 

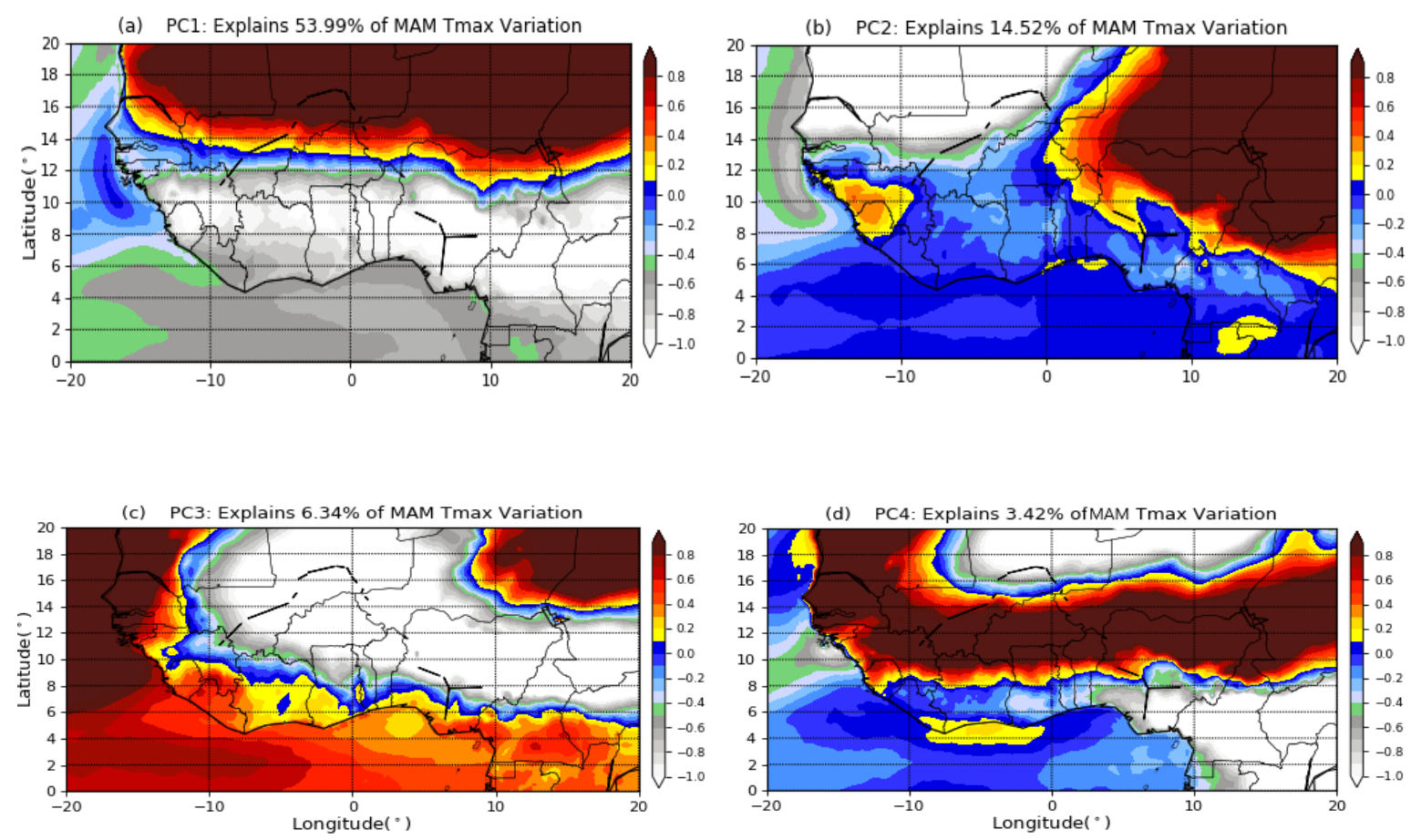

Figure 4: Principal Component Analysis of maximum temperature over West Africa during March, April and May (1979-2008)

For the minimum temperature data, the PCs explains $77.59 \%$ percentage of the explained variance from the four PCs conducted revealed different percentage of variance for the 30-year period. PC1 explained 54.26\% of variance, $13.80 \%$ of variance is explained by PC2, PC3 explained $6.12 \%$ of variance while $3.41 \%$ of variance is explained by PC4 for March, April and May (Figure 5).

(a) PC1: Explains $54.26 \%$ of MAM Tmin Variation

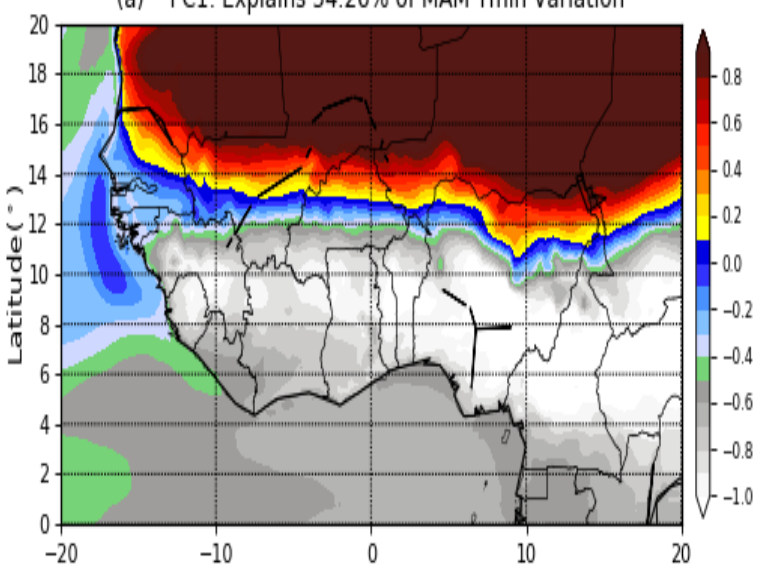

(b) PC2: Explains $13.80 \%$ of MAM Tmin Variation

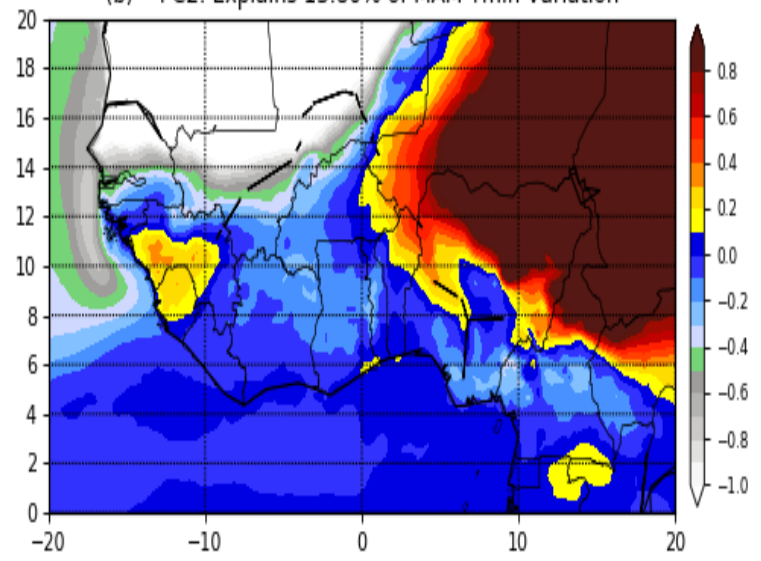


(c) PC3: Explains $6.12 \%$ of MAM Tmin Variation

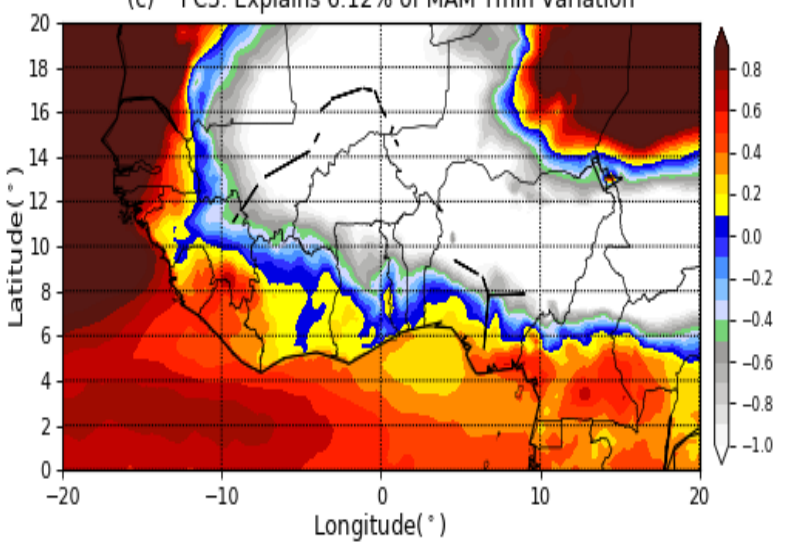

(d) PC4: Explains $3.41 \%$ of MAM Tmin Variation

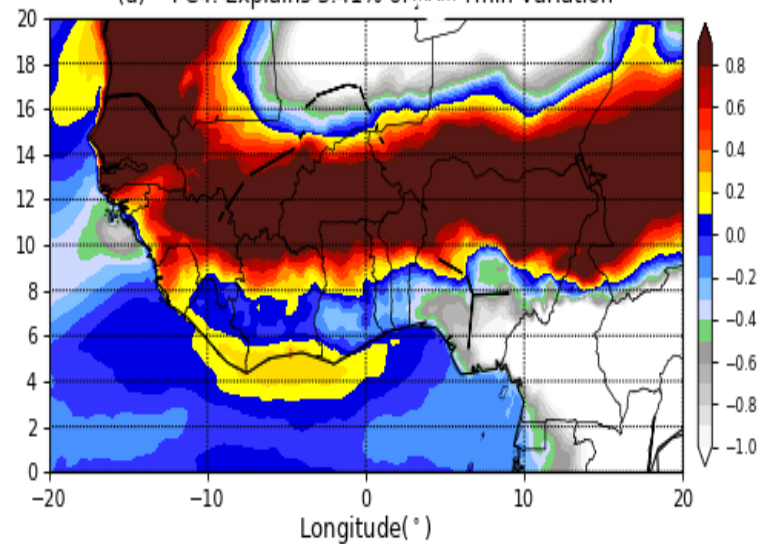

Figure 5: Principal Component Analysis of minimum temperature over West Africa during March, April and May (1979-2008)

The retained four PCs explain $49.88 \%$ percentage of variance in the daily maximum temperature data for June, July, August and September (Figure 6). The percentage of explained variance in the maximum temperature data from the four PCs conducted varies for the 30-year period. For the 1979-2008 period, $27.29 \%$ of variance is explained by PC1, $10.31 \%$ of variance is explained by PC2, PC3 revealed $6.28 \%$ and $5.80 \%$ of variance is explained by PC4 for the month of June, July, August and September.

(a) PC1: Explains $27.49 \%$ of JJAS Tmax Variation

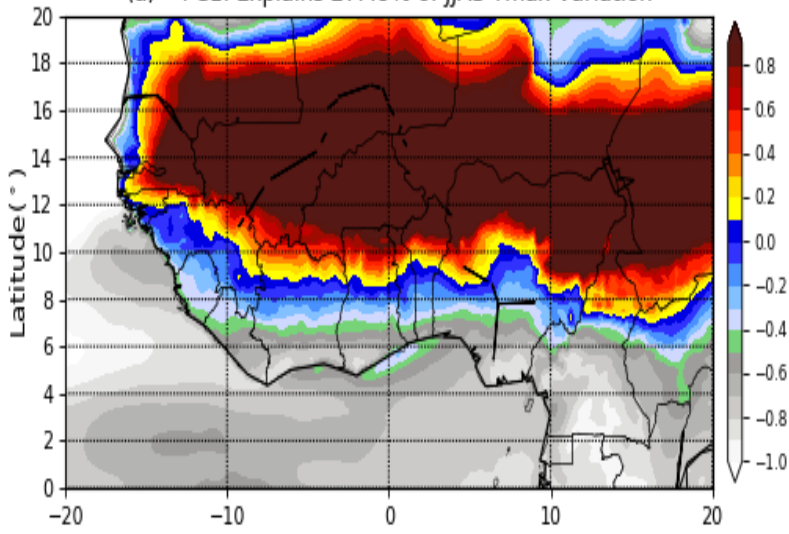

(b) PC2: Explains $10.31 \%$ of JJAS Tmax Variation

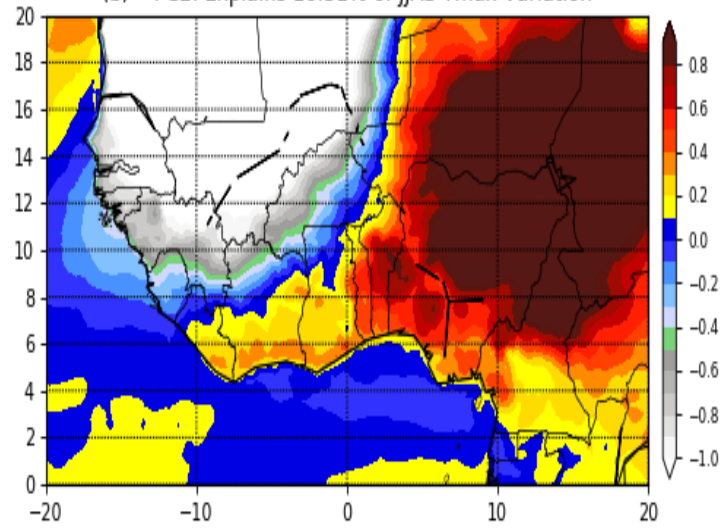



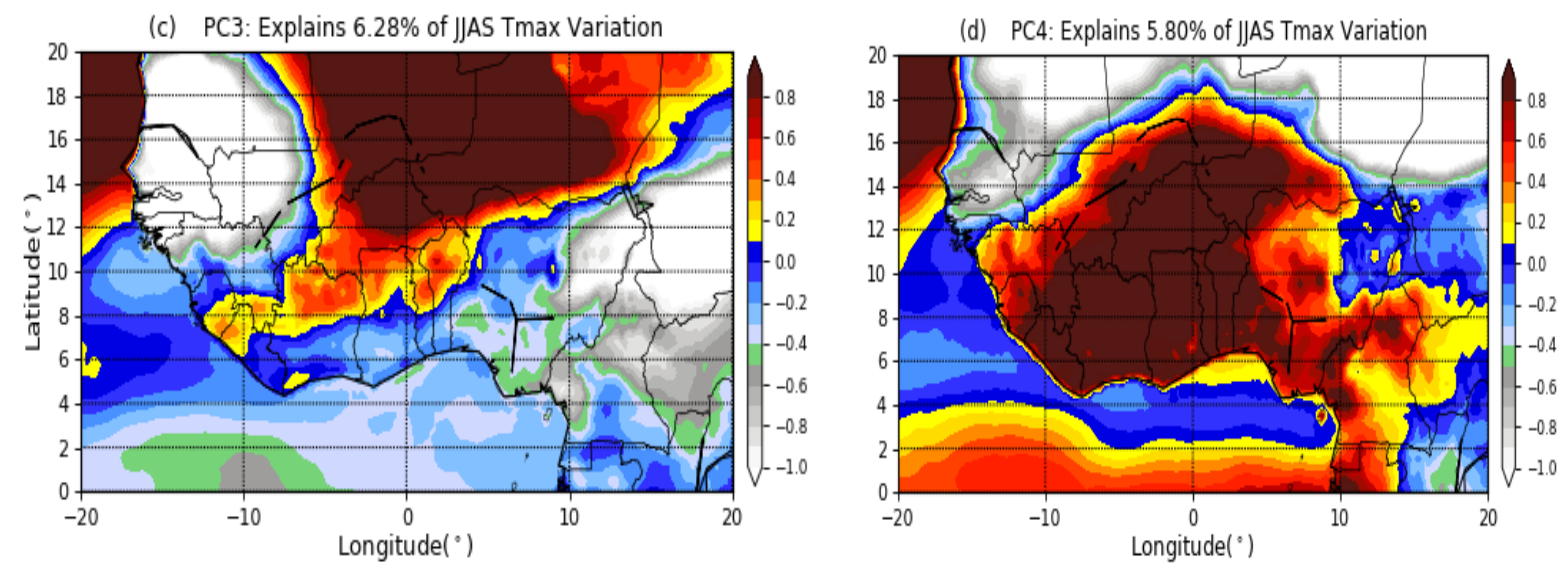

Figure 6: Principal Component Analysis of maximum temperature over West Africa during June, July, August and September (19792008)

For the minimum temperature data, the PCs explains $47.82 \%$ percentage of the explained variance from the four PCs conducted shown different percentage of variance for the 30 -year period. PC1 explained $26.49 \%$ of variance, $9.62 \%$ of variance is explained by PC2, PC3 explained 5.92\% of variance while 5.79\% of variance is explained by PC4 for June, July, August and September (Figure 7).

(a) PC1: Explains $26.49 \%$ of JJAS Tmin Variation

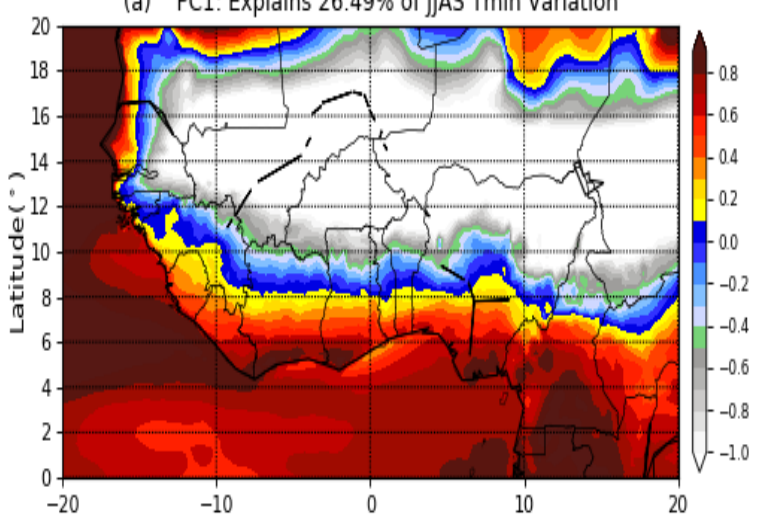

(b) PC2: Explains $9.62 \%$ of JJAS Tmin Variation

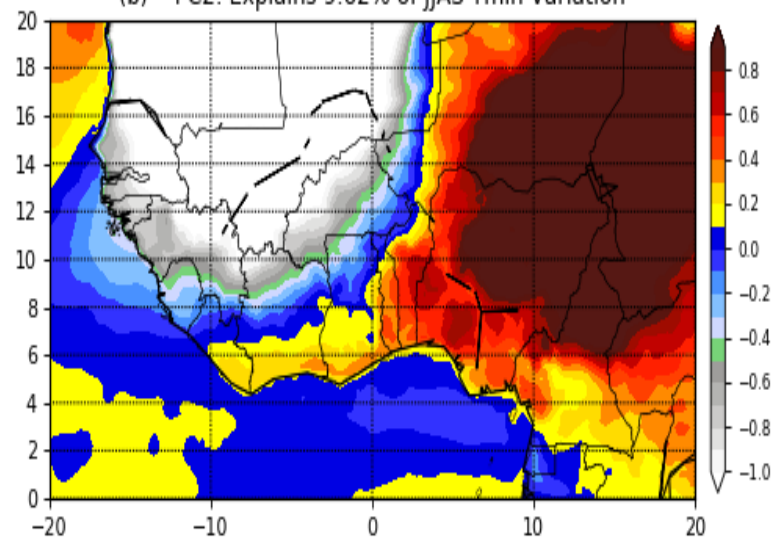


(c) PC3: Explains $5.92 \%$ of JJAS Tmin Variation

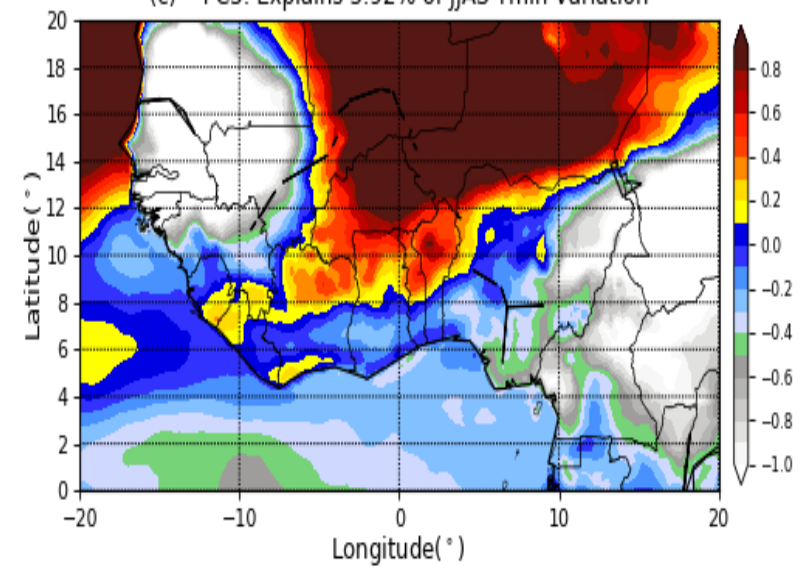

(d) PC4: Explains $5.79 \%$ of JJAS Tmin Variation

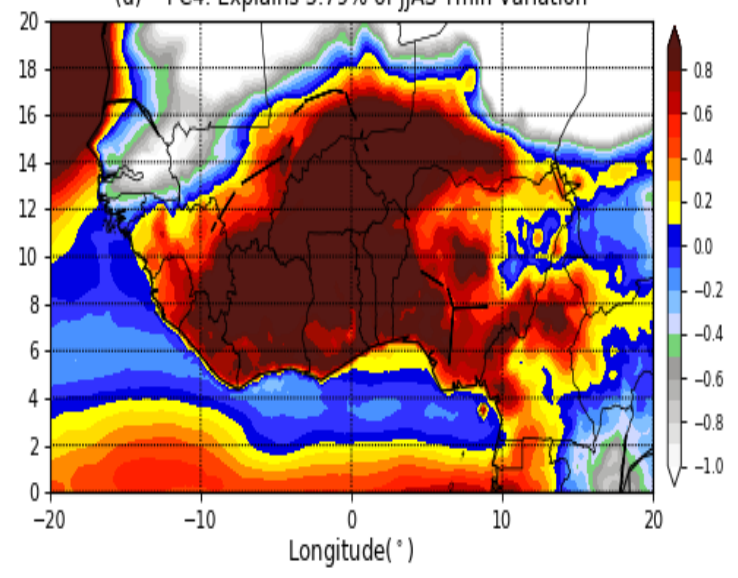

Figure 7: Principal Component Analysis of minimum temperature over West Africa during June, July, August and September (19792008)

The rotated PC1 which is the most important mode of variability in the daily maximum temperature data explains $53.99 \%$ of variance in the temperature variability for March, April and May while the results from the rotated PC1 revealed 27.29\% of variance for the June, July, August and September over West Africa. High positive PC1 loadings ( $>0.5)$ are located at the south Atlantic Ocean and Sahel parts of West Africa) while the highly negative component loadings (<-0.5) are located at along the southern Guinea Coast and the fringes of the coastal cities over West Africa for March, April and May (MAM) and June, July, August and September (JJAS).

The rotated PC2 explains $13.80 \%$ for March, April and May and 10.31\% for June, July, August and September of the variance in the maximum temperature data. The PC2 describes a mode of temperature variation in which the Sudan-Sahel indicated the highest maximum temperature and decrease towards to South and extends to north parts of Guinea Coast.

PC3 explains $6.12 \%$ of the variance in the maximum temperature data and the highest temperature is located at the eastern Sudan-Sahel above the fringes of Northern Nigeria for the March, April and May while PC3 for June, July, August and September explains $6.28 \%$ of the variance in the maximum temperature data with the highest temperature situated on the Western Sudan-Sahel.

The PC4 explains $3.42 \%$ of the variance in the maximum temperature data and the highest temperature is located at from the Eastern Sahel towards Western Sudan-Sahel for March, April, and May while the PC4 explains 5.80\% of the variance in the maximum temperature data highest temperature located over Western Sudan-Sahel extending to the Guinea Coast over Benin, Ghana, Ivory Coast, Sierra Leone and Liberia coastal cities. Generally, PC1 and PC2 depicted to be the major contributors in the temperature variations over the land, places with high PC loadings are expected to be hotter on days with high positive PC score and colder on days with highly negative PC score.

\section{Climate Indices}

\section{Percentile-based indices}

\section{(a) Sudan-Sahel Zone}

Percentile-based climate extreme indices were calculated using the baseline reference period of 1979-2008 to make results concise. It was shown that the percentile-based thresholds were sensitive to the method of computation. The monthly and annual TX90 (number of hot days) for the Heatwave Amplitude had increased at the $90^{\text {th }}$ percentile with the peak daily value of $39.13^{\circ} \mathrm{C}$ in 1998 while the Heatwave Amplitude using Excess Heat Factor revealed the highest value of $2.9^{\circ} \mathrm{C}$ in 2002 from 1979 to 2008 over Sudan-Sahel Zone (Figure 8). The TN90(number of Coldnights[annually]) for the Coldwave Amplitude had increased at the $90^{\text {th }}$ percentile with the coldest daily value of $34.72^{\circ} \mathrm{C}$ in 2000 while the Coldwave Amplitude using Excess Heat Factor revealed the lowest value of $-43.48^{\circ} \mathrm{C}$ in 1993 over Sudan-Sahel Zone. 


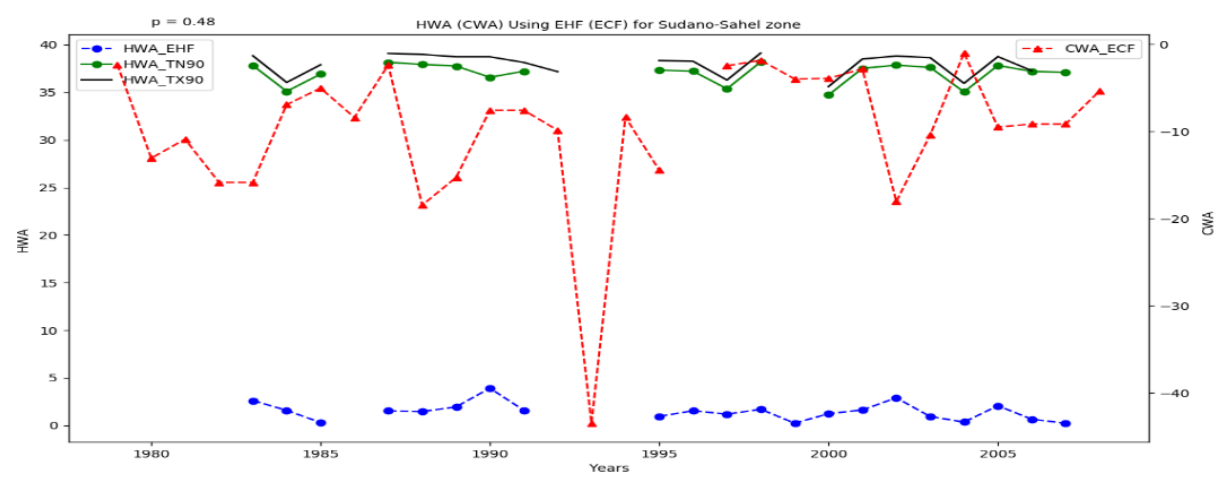

Figure 8: Heat/Cold Wave Amplitude Sudan-Sahel Zone

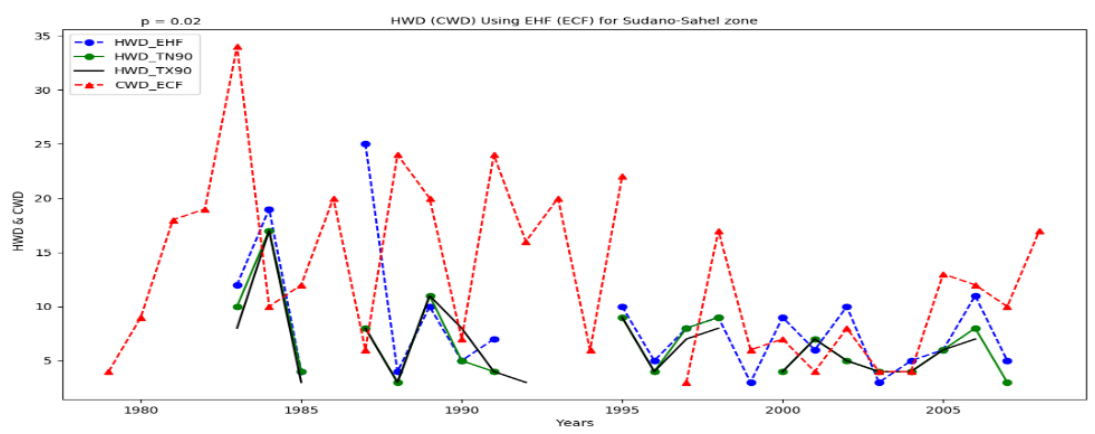

Figure 9: Heat/Cold Wave Duration over Sudan-Sahel Zone

Heatwave Duration of the monthly annual TX90 shown an increase at the $90^{\text {th }}$ percentile length of the longest heatwave identified by Heatwave Number as 17 days in 1984 and shortest heatwave duration as 3days in 1985, 1988, 1992 and 2007 while the Heatwave duration using Excess Heat Factor recorded the highest value as 25 days in 1987 and lowest as 3 days in 1999 from 1979-2008 over Sudan-Sahel zone. The TN90(number of cold nights[annually]) for the Coldwave Duration using the Excess Cold Factor indicated the longest Coldwaves as 34 days in 1983 and shortest Coldwaves as 3 days in 1997 from 1979-2008 over Sudan-Sahel zone while the Coldwaves duration using Excess Cold Factor recorded the highest value as 34days in 1983 and lowest as 3 days in 1997 over SudanSahel Zone (Figure 9).

Heatwave Frequency of the monthly and annual TX90 (number of hot days) indicating the total number of days that contributed to the heatwave as identified by the Heatwave Number progressively increased at the $90^{\text {th }}$ percentile from 1979-2008 with peak value of 49 days in 1987 while the Heatwave Frequency using Excess Heat Factor recorded 60 days as the highest value in 1987 over the SudanSahel Zone (Figure 10). The TN90(number of cold nights[annually]) for the Cold wave Frequency of the monthly increased at the $90^{\text {th }}$ percentile from 1979-2008 with the highest value 48 days in 1987 while the Coldwaves frequency using the Excess Heat Factor revealed peak duration of 45 days in 1983 over the Sudan-Sahel Zone. 


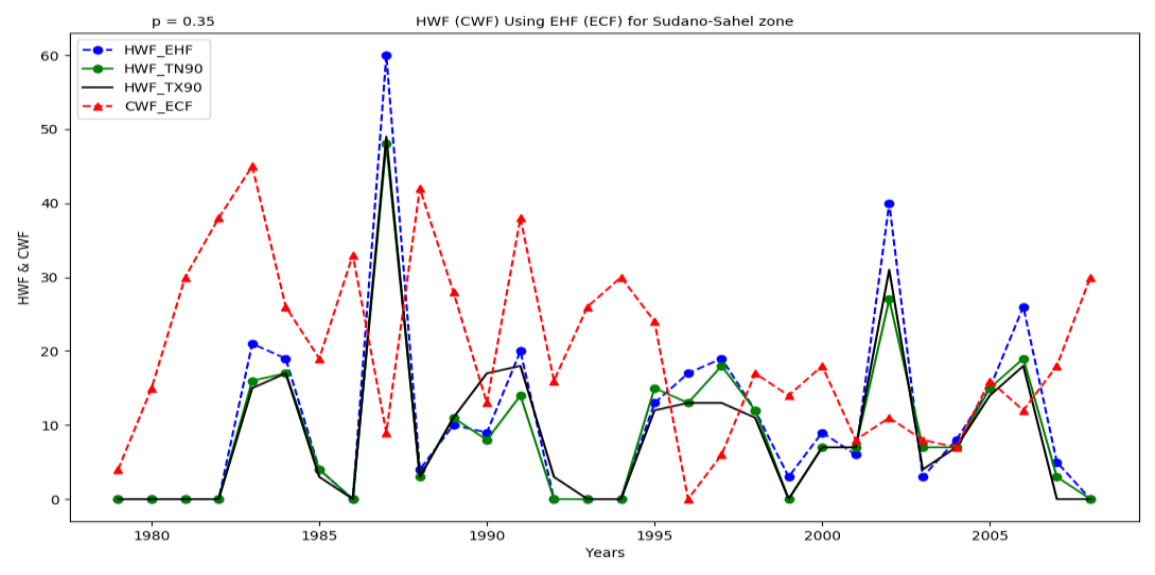

Figure 10: Heat/Cold Wave Frequency over Sudan-Sahel Zone

Monthly and annual TX90 for the Heatwave Magnitude recorded the highest mean temperature of all heatwaves identified by the Heatwave Number as $38.6^{\circ} \mathrm{C}$ in 1988 while the Heatwave magnitude using Excess Heat Factor depicted the peak value of $1.4^{\circ} \mathrm{C}$ in 1989 from 1979 to 2008 over the Sudan-Sahel Zone. The TN90(number of cold nights[annually]) for the Cold Wave Magnitude decreased at the $90^{\text {th }}$ percentile from 1979 to 2008 , depicted its lowest value as $34.2^{\circ} \mathrm{C}$ in 1984 and highest magnitude in 1988 as $37.6^{\circ} \mathrm{C}$ over the Sudan-Sahel Zone while the Coldwaves Magnitude using the Excess Cold Factor revealed a decrease from 1979 to 2008 with the coldest magnitude as -8.2 in 1993 over the Sudan-Sahel Zone. (Figure 11)

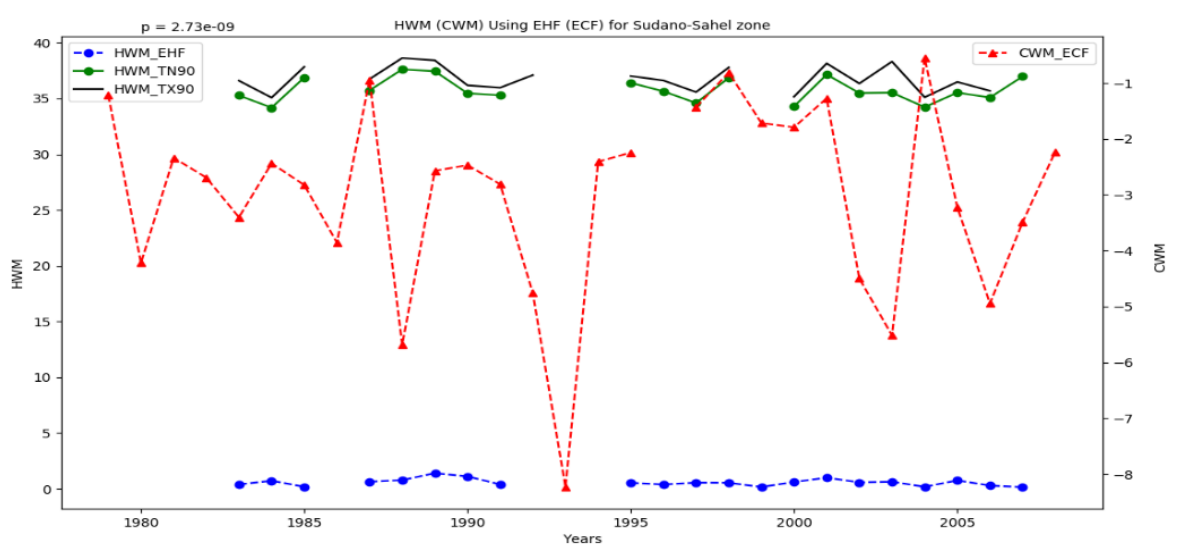

Figure 11: Heat/Cold Wave Frequency over Sudan-Sahel Zone

In Sudan-Sahel Zone, the monthly and annual TX90 Heatwave Number depicted the number of individual heatwaves as increased at the $90^{\text {th }}$ percentile from 1979 to 2008 with a peak value as 10 events in 1987 while the Heatwave number using the Excess Heat Factor recorded 9 events as the highest value in 2002 over the Sudan-Sahel Zone. The TN90(number of cold nights[annually]) for the Coldwave Number revealed the highest number of individual Coldwaves as 6 events in 1994 while the Coldwave Number using the Excess Cold Factor recorded the highest number of 9 events in 1987 from 1979-2008 over the Sudan-Sahel Zone. (Figure 12) 


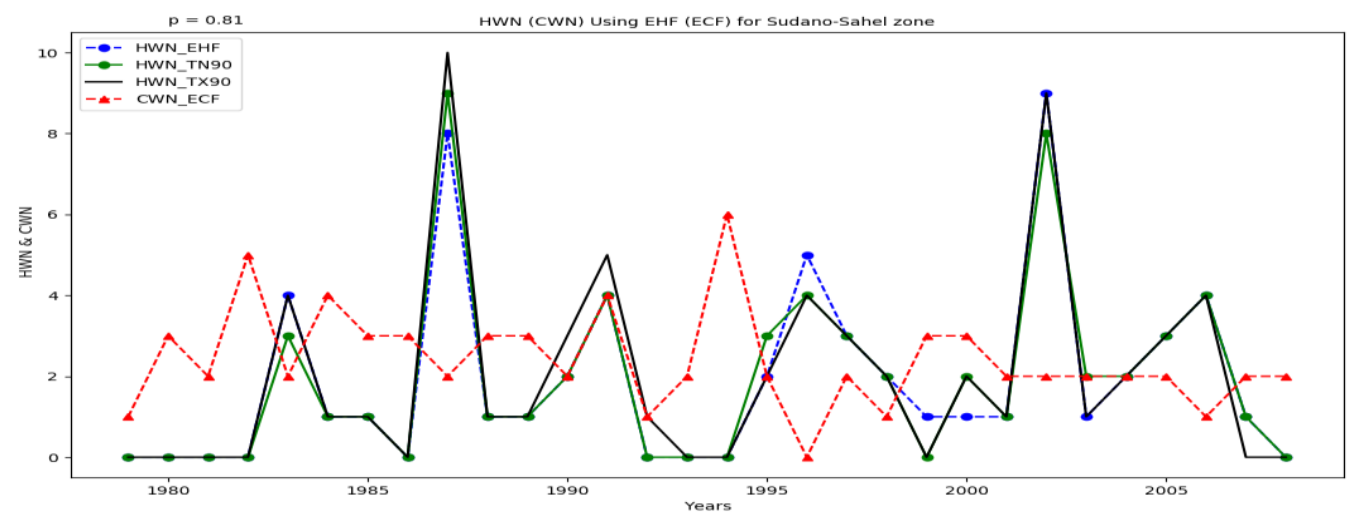

Figure 12: Heat/Cold Wave Number over Sudan-Sahel Zone

\section{(b) Guinea Coast Zone}

The monthly and annual TX90 (number of hot days) for the Heatwave Amplitude had increased at the $90^{\text {th }}$ percentile with the peak daily values of $32.56^{\circ} \mathrm{C}$ in 1987 and lowest Heatwave Amplitude value of $28.15^{\circ} \mathrm{C}$ while the Heatwave Amplitude using the Excess Heat Factor revealed an increase in the number of hot days with the highest value of $1.25^{\circ} \mathrm{C}$ in 1990 and lowest value of $0.32^{\circ} \mathrm{C}$ in 2007 from 1979-2008 over Guinea Coast Zone. (Figure 13) The TN90(number of cold nights[annually]) for Coldwave Amplitude increased at the $90^{\text {th }}$ percentile with the peak daily values of $31.89^{\circ} \mathrm{C}$ in 1987 and lowest number of cold nights as $27.63^{\circ} \mathrm{C}$ in 1984 while the Coldwave Amplitude using the Excess Cold Factor recorded the coolest nights as $-0.12^{\circ} \mathrm{C}$ from $1979-2008$ over the Guinea Coast Zone.

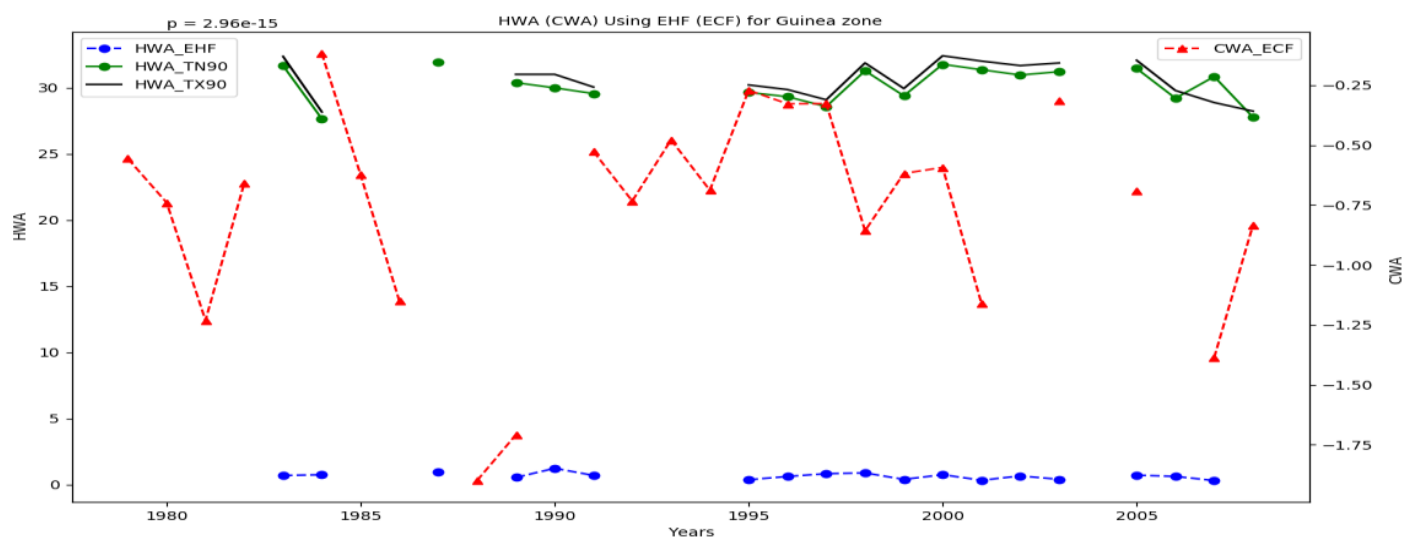

Figure 13: Heat/Cold Wave Amplitude over Guinea Zone

Heatwave Duration of the monthly annual TX90 (number of hot days) shown an increase at the $90^{\text {th }}$ percentile length of the longest heatwave identified by Heatwave Number as 14 days in 1987 and Shortest Heatwave Duration as 3 days in 2007 and 2008 while the Heatwave Duration using the Excess Heat Factor revealed an increase with the peak Heatwave Duration as 13days in 1998 and lowest number of hot days as 3 days in 1983, 2001 and 2007 from 1979-2008 over the Guinea Coast Zone. The TN90(number of cold nights[annually]) for Coldwave Duration increased at $90^{\text {th }}$ percentile with the peak daily values of 14 days in 1987 and the Shortest Coldwave Duration revealed was 3 days in 1995, 2007 and 2008 from 1979-2008 over the Guinea Coast Zone. The Excess Cold Factor shown an increase with the peak Coldwave Duration as 17 days in 1994 and 3 days in 1984, 1993, 1995, 1996, 1997 and 2003 respectively from 1979-2008 over Guinea Coast Zone. (Figure 14) 


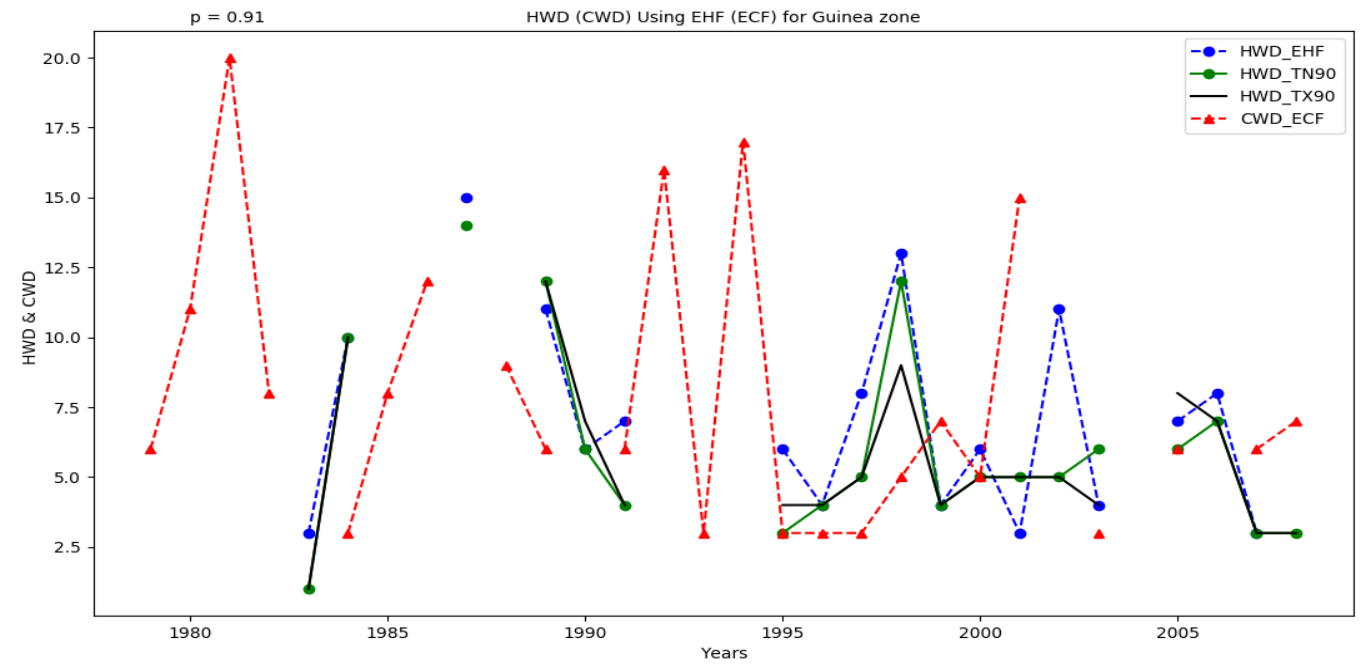

Figure 14: Heat/Cold Wave Duration over Guinea Zone

Heatwave Frequency of the monthly and annual TX90 (number of hot days) indicating the total number of days that contributed to the heatwave as identified by the Heatwave Number progressively increased at the $90^{\text {th }}$ percentile from 1987 with peak value of 58 days in 1987 and the lowest value of 3 days in 2007 and 2008 while the Heatwave Frequency using the Excess Heat Factor revealed an increase with the highest value of 54 days in 1987 and lowest value of 3days in 1983 and 2001 respectively from 1979-2008 over Guinea Coast Zone. The TN90(number of cold nights[annually]) for the Cold wave Frequency of the monthly increased at the $90^{\text {th }}$ percentile from 1979-2008 with the highest value of 48 days in 1987 and lowest value of 3 days in 2008 while the Coldwave Frequency using the Excess Heat Factor depicted an increase with the peak value of 47days in 1994 and lowest value of 3 days in 1984,1993, 1995, 1996 and 1997 respectively from 1979-2008 over Guinea Coast Zone. (Figure 15)

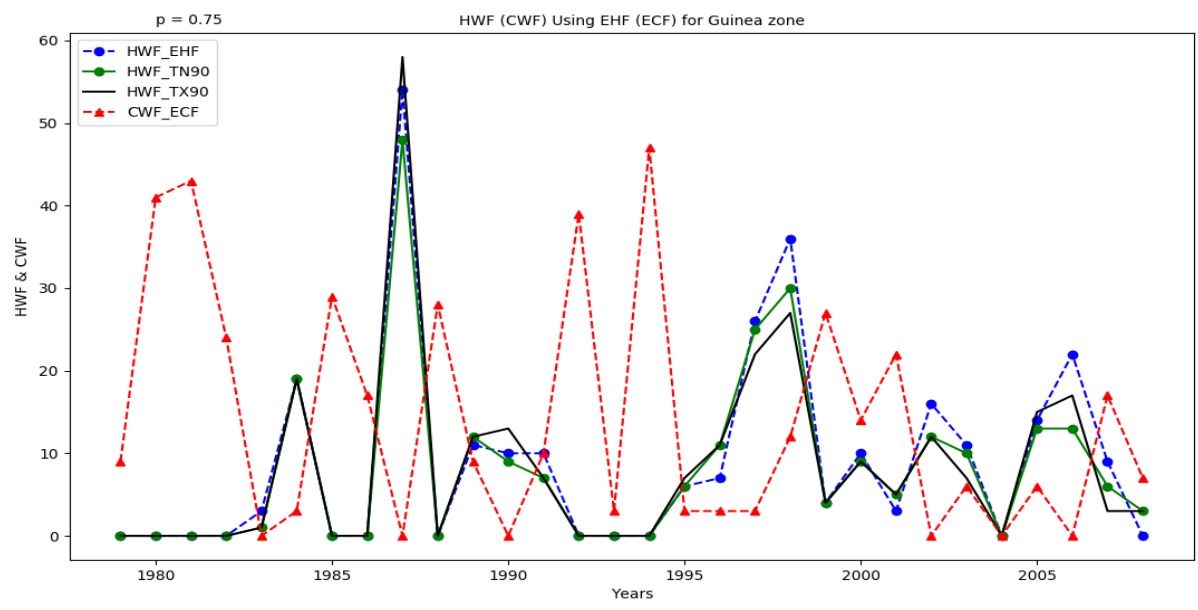

Figure 15: Heat/Cold Wave Frequency over Guinea Zone

Monthly and annual TX90 (number of hot days) for the Heatwave Magnitude recorded the highest mean temperature of all heatwaves identified by the Heatwave Number as $32.3^{\circ} \mathrm{C}$ in 1983 and the lowest value of $27.77^{\circ} \mathrm{C}$ in 1984 while the Heatwaves Magnitude using the Excess Heat Factor revealed the highest value of $0.45^{\circ} \mathrm{C}$ in 1990 and the lowest value of $0.12^{\circ} \mathrm{C}$ in 2007 from $1979-2008$ over Guinea Coast Zone. The TN90(number of cold nights[annually]) for the Coldwave Magnitude decreased at the $90^{\text {th }}$ percentile from 1979-2008 with the coolest value of $27.22^{\circ} \mathrm{C}$ in 1984 while the Coldwave Magnitude using the Excess Coldwave Factor recorded the coolest value of $-0.76^{\circ} \mathrm{C}$ in 1989 over the Guinea Coast Zone. (Figure 16)

\section{www.scirj.org}

(C) 2021, Scientific Research Journal

http://dx.doi.org/10.31364/SCIRJ/v9.i09.2021.P0921879

This publication is licensed under Creative Commons Attribution CC BY. 


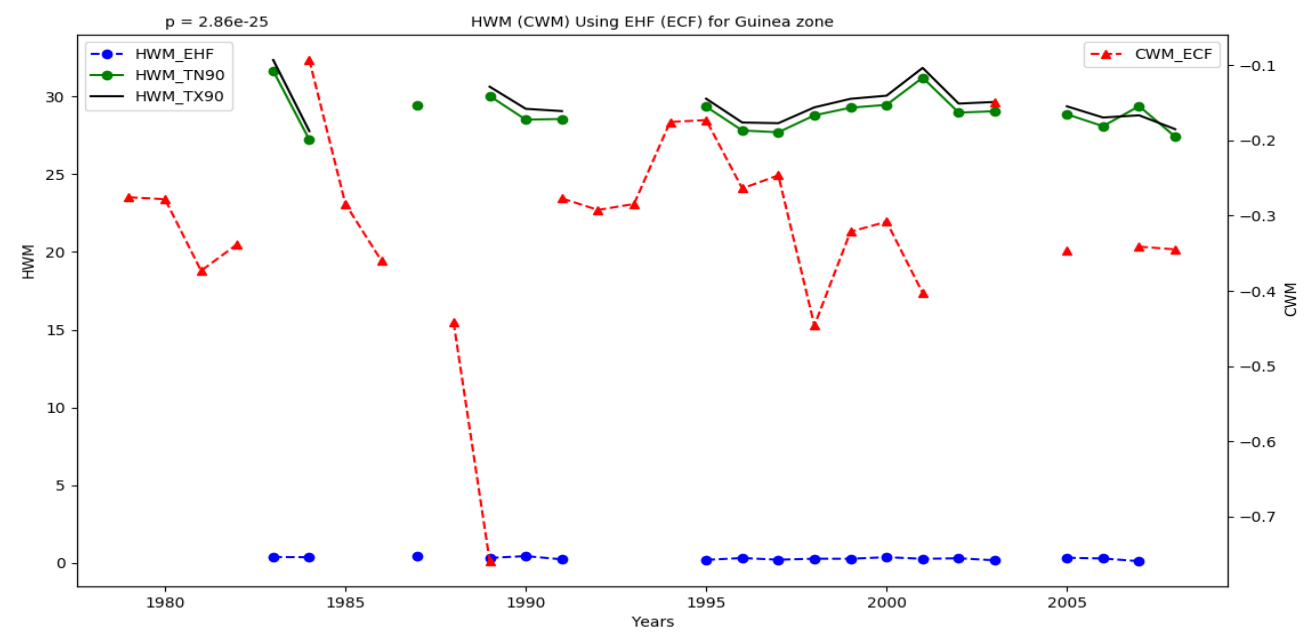

Figure 16: Heat/Cold Wave Magnitude over Guinea Zone

In Guinea Coast Zone (Figure 17), the monthly and annual TX90 for the Heatwave Number depicted the number of individual heatwaves as increased at the $90^{\text {th }}$ percentile with the Heat Wave Number of 10 events in 1987 and the lowest value of 7 events in 1994 while the Heatwave Number using the Excess Heatwave depicted the highest number of individual heatwaves of 6 events in 1997 and lowest value of 3 events in 2003, 2005 and 2007 from 1979-2008 over the Guinea Coast Zone. The TN90(number of cold nights[annually]) Coldwave Number for the Coldwave Number revealed the highest number of individual Coldwaves as 7 events in 1987 and 1997 while the Coldwave Number using the Excess Cold Factor recorded the highest number of 7 events and lowest number 1 event in 1984, 1993, 1995, 1996, 1997, 2005 and 2008 over the Guinea Coast Zone.

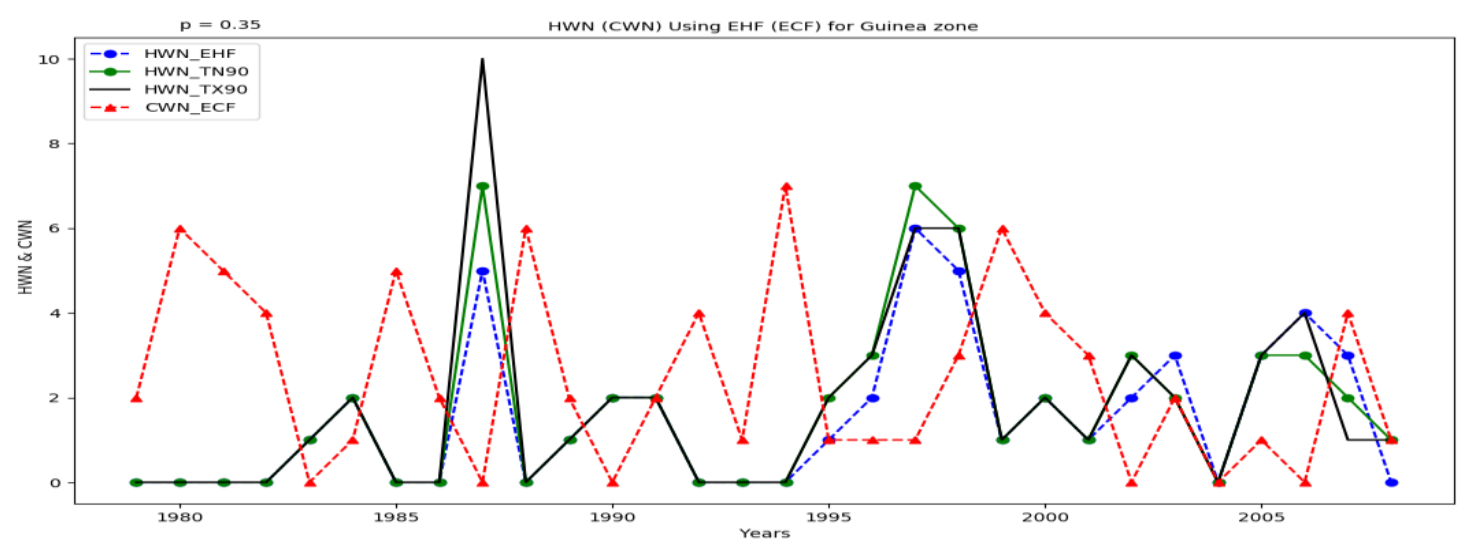

Figure 17: Heat/Cold Wave Number over Guinea Zone

\section{Conclusion}

This study revealed a warming trend of temperature over West Africa which will pose a negative impact on human health and the economy. Anthropogenic activities leading to heatwave events need to be reduced through behavioral changes and switch to renewal energy systems for a cleaner and cooler environment. Heat wave amplitude has increased significantly at $90^{\text {th }}$ percentile from 19792008 with the highest value of $2.9^{\circ} \mathrm{C}$ in 2002 and 17 days of heatwave duration in 1998 over Sudan-Sahel in West Africa. Coldwave Amplitude had increased at the $90^{\text {th }}$ percentile with the coldest daily value of $34.72^{\circ} \mathrm{C}$ in 2000 , Coldwave Duration using the Excess

www.scirj.org

(C) 2021, Scientific Research Journal

http://dx.doi.org/10.31364/SCIRJ/v9.i09.2021.P0921879

This publication is licensed under Creative Commons Attribution CC BY. 
Cold Factor indicated the longest Coldwaves as 34 days in 1983 and shortest Coldwaves as 3 days in 1997 from 1979-2008 over SudanSahel zone, which implies that duration of the Coldwaves decreased as the year progresses while the heatwave duration increased, in agreement with the changing climate.

The Guinea Coast zone depicted an increase in the heat wave amplitude with the peak value $32.56^{\circ} \mathrm{C}$ in 1987 at $90^{\text {th }}$ percentile and the heatwave duration increased from 1979-2008 with a record of 14 days in 1987. Coldwave Amplitude increased at the $90^{\text {th }}$ percentile with the peak daily values of $31.89^{\circ} \mathrm{C}$ in 1987 and Coldwave Duration increased at $90^{\text {th }}$ percentile with the peak daily values of 14 days in 1987 and the Shortest Coldwave Duration revealed was 3 days in 1995, 2007 and 2008 from 1979-2008 over the Guinea Coast Zone. The decrease in coldwave duration and increase in heatwave duration as the year progresses is in agreement with the report of Intergovernmental Panel on Climate Change (IPCC) working Group I (2021) of code red for humanity as the internationally agreed threshold of $1.5^{\circ} \mathrm{C}$ is perilously close.

There is need to increase studies on projections of heat and cold waves over West Africa for climate adaptation and mitigation plans to achieve a sustainable future.

\section{References}

Alexander, L. V., Zhang, X., Peterson, T. C., Caesar, J., Gleason, B., Klein Tank, $\quad$ A. M. G., Haylock, M.,Collins, D., Trewin, B., Rahimzadel, F., Tagipour, A., Rupa Kumar, K, Revadekar, J., Griffiths, G.,Vincent, L., Stephenson, D. B., Burn, J., Aguilar, E., Brunet, M., Taylor, M., New, M., Zhai, P., Rusticucci, M. and J. L.Vazquez-Aguirre (2006). Global observed changes in daily climate extremes of century. Clim. Res., 19, 193 - 212.

Catell, R.B (1966). The Scree test for the number of factors. Multiva. Behav. Res.1, 245-276. doi:10.1207/s1532790mbr012.10.

Donat. M. G., Peterson, T. C., Brunet, M., King, A. D., Almazroui, M., Kolli, R. K., Boucherf, D., Al-Mulla, A. Y., Nour, A. Y., Aly, A. A., Nada T. A.A, Semawi, M. M., Al Dashti, H. A., Salhab, T. G., El Fadli, K. I, Muftah, M. K., Eida, S. D., Badi, W., Driouech, F., Khalid, E. 1. Rhaz, K., Abubaker, M. J. Y., Ghulam, A. S., Erayah, A.S., Mansour, M. B., Alabdouli, W. O., Al Dhanhani, J. S. and M. N. Al Shekaili (2013). Changes in extreme temperature and precipitation in the Arab region: longterm trends and variability related to ENSO and NAO. Int. J. Climatol., DOI: 10.1002/joc.3707.

Easterling, D. R. et al. (1997). Maximum and minimum temperature trends for the globe. Science, $277,364-367$.

Frich, P., Alexander, L.V., Della-Marta, P., Gleason, B., Haylock, M., Tank, A. M. G. K. and T. Peterson (2002). Observed coherent changes in climatic extremes during the second half of the twentieth century. Clim. Res., 19, 193 - 212.

Guo Y, Gasparrini A, Armstrong BG, Tawatsupa B, Tobias A, Lavigne E, et al. (2017). Heat Wave and Mortality: A Multicountry, Multicommunity Study. Environmental Health Perspectives 087006, 229-240. https://doi.org/10.1289/EHP1026 PMID: 28886602.

Habeeb D, Vargo J, Stone B Jr, (2005). Rising heat wave trends in large US cities. Nat. Hazards 76:1651-1665. https://doi.org/10.1007/s11069-014-1563-z.

IPCC (2021). Summary for Policymakers. In: Climate Change 2021: The Physical Science Basis. Contribution of Working Group I to the Sixth Assessment Report of the Intergovernmental Panel on Climate Change [Masson-Delmontte, V., P. Zhai, A. Pirani, S. L., Connors, C. Pean, S. Berger, N. Caud, Y. Chen, L. O. Yelekci, R. Yu and B. Zhou (eds.)]. Cambridge University Press. In Press.

Kaiser, H.F. (1960). The Application of electronic computers to factor analysis. Educ. Psychol. Meas. 20, 141-151. doi:10.1177/001316446002000116.

Meehl, G. A. and C. Tebaldi (2004). More intense more frequent, and longer lasting heatwaves in the 21st century. Science, 305, 994997.

Moron V, Oueslati B, Pohl B, Rome S, Janicot S (2016). Trends of mean temperatures and warm extremes in northern tropical Africa (1961-2014) from observed and PPCA-reconstructed time series.

$$
\text { www.scirj.org }
$$

(C) 2021, Scientific Research Journal

http://dx.doi.org/10.31364/SCIRJ/v9.i09.2021.P0921879

This publication is licensed under Creative Commons Attribution CC BY. 
Nairn, J. and R. Fawcett (2013). Defining heatwaves: heatwave defined as a heat-impact event servicing all community and business sectors in Australia. The Centre for Australian Weather and Climate Research- a partnership between CSIRO and the Bureau of Meteorology, CAWCR Technical Report No. 060.

Omotosho J B, Abiodun B J (2007). A numerical study of moisture buildup and rainfall over West Africa. Meteorol Appl 14(3):209225. https ://doi.org/10.1002/met11.

Perkins, S.E \& Alexander, L.V. (2013). On the measurement of heat waves. J. Clim 26(13):4500-4517. doi:10.1175/JCLI-D-1200383.1.

Perkins S.E, Alexander L.V, \& Nairn, J.R (2012). Increasing frequency, intensity and duration of observed global heatwaves and warm spells. Geophys. Res. Lett. 39: 1-5. doi: 10.1029/2012GL053361.

Peterson, T. C., Taylor, M. A., Demeritte, R., Duncombe, D. L., Burton, S., Thompson, F. and B. Gleason (2002). Recent changes in climate extremes in the Caribbean region. J. Geophy. Res.-Atmos., 107(D21). DOI: 10.1029/2002jd002251.

Robinson, P. J. (2001). On the Definition of a Heat Wave. J. Appl. Meteor., 40, 762-775.

Smith TT, Zaitchik BF, Gohlke JM (2013). Heat waves in the United States: definitions, patterns and trends. Clim. Change 118(3-4): 811-825. https://doi.org/10.1007/s10584-012-0659-2 PMID: $23869115 /$

Tong, S., Fitzgerald, G.,Wang, X.Y., Aitken, P., Tippett, V., Chen, D., et al., (2015). Exploration of the health risk-based definition for heatwave: amulti-city study. Environ. Res. 142, 696-702.

Watt, J. D. and L. Kalkstein (2004). The Development of a Warm-Weather Relative Stress Index for Environmental Applications. J. Appl. Meteorol., 43,503-513.

Xu, Z., FitzGerald, G., Guo, Y., Jalaludin, B., Tong, S., (2016). Impact of heatwave on mortality under different heatwave definitions: a systematic review and meta-analysis. Environ. Int. 90, 193-203.

Yang, J., Zhou, M., Li, M., Liu, X., Yin, P., Sun, Q., et al., (2018). Vulnerability to the impact of temperature variability on mortality in 31 major Chinese cities. Environ. Pollut. 239, 631-637.

Yi L, Yihui D, Weijing L (2017). Observed Trends in Various Aspects of Compound Heat Waves across China from 1961 to 2015. Journal of Meteorological Research. https://doi.org/10.1007/s13351-017- 6150-2.

www.scirj.org

(C) 2021, Scientific Research Journal

http://dx.doi.org/10.31364/SCIRJ/v9.i09.2021.P0921879

This publication is licensed under Creative Commons Attribution CC BY. 